\title{
PENGARUH FAKTOR MODEL, MUTU DAN HARGA TERHADAP KEPUTUSAN PEMBELIAN PRODUK SARUNG TENUN PADA USAHA KECIL DAN MENENGAH (UKM) DI PARENGAN MADURAN LAMONGAN
}

\author{
Ana Fitriyatul Bilgies \\ Hafidz Nasrullah \\ Fakultas Ekonomi Universitas Islam Darul `Ulum Lamongan \\ bilgiespinkz@gmail.com \\ hafidhnasrullah01@gmail.com
}

\begin{abstract}
The purpose of this study was to analyze the effect of model, quality and price factors on purchasing decisions on woven sarong products in Small and Medium Enterprises in Parengan Maduran Lamongan. The data used in this study are primary data obtained from the questionnaire. The population in this study is 1650 Consumers at CV. Paradila and 1350 CV. Bintang Mas, resulting in a total population of 3000 consumers. While samples with Slovin formula obtained as many as 97 people. Sampling Technique. In this research, purposive sampling method was used. Purposive sampling is a sampling technique with certain considerations. The analytical techniques used are validity, reliability, classical assumptions, multiple linear regression, $T$ test and $F$ test and $R$ determination of research results. The results of the multiple linear regression equation formed are as follows: $Y=0.465+1.025 X 1+0.219 X 2+0.045$ $X 3+e$. Based on the F test, it can be seen that the Fcount value is 128.51> Ftable value of 2.70. This proves that the Model, Quality and price variables simultaneously influence the Purchasing decision of woven sarongs. 1,661, Quality (X2) 3,164> 1,661 and Price (X3) 0,418<1,661. Thus the Model variable that most influences the Decision variable Purchases woven sarongs while the coefficient of determination test is equal to $77.9 \%$ The decision to purchase woven sarongs is influenced by variations in the three variables used in the study, the remaining $22.1 \%$ are influenced by other variables
\end{abstract}

Keywords: Model, Quality, Price and buying decision

Abstrak: Tujuan penelitian ini adalah untuk menganalisis Pengaruh faktor model, mutu dan harga terhadap keputusan pembelian produk sarung tenun pada Usaha Kecil dan Menengah di Parengan Maduran Lamongan. Data yang digunakan dalam penelitian ini adalah data primer yang diperoleh dari kuesioner. Populasi pada penalitian ini adalah Konsumen di CV.Paradila sebanyak 1650 Konsumen dan CV.Bintang Mas sebanyak 1350 sehingga total populasi 3000 konsumen. Sedangkan sampel dengan rumus Slovin diperoleh sebanyak 97 orang. Teknik Sampling.dalam penelitian ini digunakan metode purposive sampling. Purposive sampling adalah teknik pengambilan sampel dengan pertimbangan tertentu. Teknik analisis yang digunakan adalah Uji validitas, reliabilitas, Asumsi Klasik, Regresi linier berganda,Uji $T$ dan Uji $F$ dan $R$ determinasi. Hasil penelitian diperoleh persamaan regresi linier berganda yang terbentuk adalah sebagai berikut $Y=0,465+1,025 X 1+0,219 X 2+0,045 X 3+e$. Berdasarkan uji $F$ dapat diketahui nilai Fhitung sebesar 128,51 > nilai Ftabel sebesar 2,70 Hal ini membuktikan bahwa variable Model, Mutu dan harga secara simultan berpengaruh terhadap Keputusan Pembelian sarung tenun.dan hasil pengujian thitung 
didapat nilai Model sebesar 7,873 (X1) > 1,661, Mutu (X2) 3.164 > 1,661 dan Harga (X3) $0,418<1,661$. Dengan demikian variabel Model yang paling berpengaruh terhadap variabel Keputusan Pembelian sarung tenun sedangkan uji koefisien determinasi yakni sebesar 79,9\% Keputusan pembelian sarung tenun dipengaruhi oleh variasi ketiga variabel yang digunakan dalam penelitian, sisanya 20,1\% dipengaruhi variabel lain.

Kata Kunci: Model,Mutu,Harga dan keputusan beli

\section{PENDAHULUAN}

Bagi perusahaan yang memproduksi jenis produk tertentu diusahakan supaya dapat atau mampu memberikan kepuasan yang diinginkan oleh konsumen dan dapat menguasai pasar sehingga akan mendapatkan keuntungan yang setinggi tingginya. Oleh karena itu penerapan strategi sangatlah membantu perusahaan sehingga dalam setiap persaingan yang ada dapat berada pada posisi yang lebih kuat dibandingkan dengan pesaing yang lain.

Kotler ( 2011, hal. 18 ) seperti diketahui perusahaan hidup dan berkembang dalam suatu lingkungan yang mengitarinya, sehingga faktor lingkungan perlu mendapat perhatian dalam pembuatan keputusan dibidang pemasaran. Kotler dan Amstrong ( 2013 ).Didalam proses pengambilan keputusan untuk melakukan pembelian sebuah produk, konsumen biasanya melalui tahap - tahap yaitu : pengendalian kebutuhan, pencarian informasi, evaluasi, alternatif, keputusan pembelian dan perilaku purna jual.

Disisi lain Pemberdayaan UMKM khususnya UKM diharapkan akan meningkatkan stabilitas ekonomi makro, karena menggunakan bahan baku lokal dan memiliki potensi ekspor, sehingga akan membantu menstabilkan kurs rupiah dan tingkat inflasi. Pemberdayaan UKM akan menggerakkan sektor riil, karena UKM umumnya memiliki keterkaitan industri yang cukup tinggi. UKM diharapkan menjadi tumpuan pengembangan di sektor perbankan yang kuat dan sehat pada masa mendatang, mengingat non-performing loannya yang sangat rendah. Pemberdayaan UKM juga akan meningkatkan pencapaian sasaran di bidang pendidikan, kesehatan, dan isbandin kesejahteraan masyarakat Indonesia lainnya.

Demikian halnya dengan industriindustri kecil penghasil sarung tenun sebagai badan usaha yang bergerak dalam bisnis penyediaan sarung tenun. Dengan semakin meningkatnya usaha dibidang serupa, berarti semakin banyak pula pilihan para pembeli dalam mencari produk yang serupa yang memenuhi selera mereka. Akan tetapi keberadaan industri kecil tersebut apabila dibandingkan dengan perusahaanperusahaan penghasil produk sejenis sangatlah jauh tertinggal. Dari sudut pemasaran, informasi tentang kelebihan yang dimiliki oleh sebuah produk sarung tenun yang diproduksi oleh sebuah perusahaan besar, dapat dilakukan dengan promosi di berbagai media massa, baik cetak maupun elektronik ataupun dengan cara mendirikan counter-counter di beberapa tempat yang strategis. Lain halnya dengan produk sarung tenun yang dihasilkan oleh industri kecil.

Permasalahan terjadi pada kawasan industri kecil sarung tenun di Parengan Kecamatan maduran Kabupaten Lamongan yang selama ini ada 2 Industri yang cukup besar dan sebenarnya sudah 
lama bergerak dalam bidang tersebut. Volume penjualan yang dicapai oleh 2 industri kecil yaitu CV.Bintang Mas dan CV. Paradila merosot pada tahun 2014, dan terdapat indikasi bahwa hasil penjualan yang dicapai oleh perusahaan tersebut sampai dengan akhir Desember 2016 relatif sulit terangkat naik. Indikasi adanya penurunan volume penjualan ini terlihat pada data tabel berikut.

Tabel 1.1 Volume Penjualan

\begin{tabular}{|l|l|c|c|c|c|}
\hline \multirow{2}{*}{ No } & \multicolumn{1}{|c|}{ Nama } & \multicolumn{4}{|c|}{ Volume Penjualan } \\
\cline { 3 - 6 } & Industri & Tahun & Tahun & Tahun & Tahun 2016 \\
& 2013 & 2014 & 2015 & \\
\hline 1 & UD. Paradila & 6451 & 5124 & 5513 & 5563 \\
\hline 2 & $\begin{array}{l}\text { UD.Bintang } \\
\text { Mas }\end{array}$ & 3451 & 2015 & 1980 & 2100 \\
\hline
\end{tabular}

Sumber : UD. Paradila dan UD.Bintang Mas

Dengan adanya penurunan volume tersebut mengakibatkan perkembangan industri akan lambat. Untuk itulah peneliti tertarik untuk melakukan penelitian dengan judul "Pengaruh Faktor Model, Mutu Dan Harga Terhadap Keputusan Pembelian Produk Sarung Tenun Pada Usaha Kecil Dan Menengah Di Parengan Maduran Lamongan"

Berdasarkan latar belakang dapat dirumuskan masalah sebagai berikut, Seberapa pengaruh faktor model, mutu dan harga terhadap keputusan pembelian produk sarung tenun pada usaha kecil dan menengah di Parengan Maduran Lamongan ? Sementara itu, penelitian ini bertujuan untuk, (1) untuk memahami pengaruh faktor model, mutu dan harga terhadap keputusan pembelian produk sarung tenun pada usaha kecil dan menengah di Parengan Maduran Lamongan, dan (2) memberikan rekomendasi berdasarkan model, mutu dan harga terhadap keputusan pembelian produk sarung tenun.

\section{KAJIAN PUSTAKA}

\section{Pengertian Manajemen Pemasaran}

Menurut Kotler (2011: 14), manajemen pemasaran adalah penganalisaan, pelaksanaan dan pengawasan program-program dengan maksud untuk mencapai tujuan organisasi. Agar tujuan organisasi tercapai maka tergantung pada penawaran organisasi dalam memenuhi kebutuhan dan keinginan pasar tersebut serta menentukan harga, mengadakan komunikasi dan distribusi yang efektif untuk memberi tahu, mendorong serta melayani pasar.

Sehubungan dengan hal itu, maka tugas pokok manajemen pemasaran adalah mempersiapkan rencana umum tersebut bagi perusahaan serta mengadakan evaluasi, menganalisa, dan mengawasi rencana tersebut dalam operasinya.

Jadi, manajemen pemasaran dirumuskan sebagai suatu proses manajemen yang meliputi penganalisaan, perencanaan, pelaksanaan, dan pengawasan kegiatan pemasaran yang dilakukan oleh perusahaan. Kegiatan ini bertujuan menimbulkan pertukaran yang diinginkan baik yang menyangkut barang ataupun jasa. Proses pertukaran baik yang ditimbulkan oleh penjual maupun pembeli yang menguntungkan kedua belah pihak, maka penentuan produk, harga, promosi dan tempat disesuaikan dengan sikap dan perilaku konsumen. Sebaliknya sikap dan perilaku konsumen dipengaruhi sedemikian rupa sehingga menjadi sesuai dengan produk-produk perusahaan. 


\section{Pengertian Marketing Mix (Bauran Pemasaran)}

Marketing Mix (Winardi, 2008: 319) adalah kelompok variabel-variabel yang dapat dikendalikan, yang dapat dipergunakan oleh perusahaan yang bersangkutan untuk mempengaruhi reaksi para pembeli. Marketing Mix (bauran pemasaran) mencakup antara lain : Produk, Harga, Saluran Distribusi dan Pormosi. Wujud produk memiliki empat karakteristik yaitu : 1) Kualitas atau mutu. 2) Ciri-ciri produk. 3) Gaya atau corak produk, 4) Kemasan.

\section{Harga}

Menurut Basu Swastha dan Irawan (2008: 99), harga adalah jaminan uang (ditambah beberapa produk kalau mungkin) yang dibutuhkan untuk mendapatkan sejumlah kombinasi dari produk dan pelayanannya. Di sini harga suatu produk jelas sekali merupakan faktor yang amat menentukan dalam perilaku konsurnen. Harga merupakan faktor penentu yang mempengaruhi pilihan pembelian, hal ini masih menjadi kenyataan di negara-negara dunia ketiga, di kalangan kelompok-kelompok sosial yang miskin, serta pada bahan-bahan pokok sehari-hari. Namun dalam dasawarsa terakhir ini, faktor-faktor lain selain harga telah beralih menjadi relatif lebih penting dalam proses pembelian. (Jurnal STAIN kudus, Vol. 9, No. 1, Februari 2015 )

\section{Saluran distribusi}

Menurut Basu Swastha dan Irawan (2008: 100), Saluran Distribusi adalah suatu jalur yang dilalui oleh arus barangbarang dari produsen keperantara akhimya sampai pada pemakai lembagalembaga yang ikut ambil bagian dalam penyaluran barang adalah sebagai berikut: 1) Produsen. 2) Perantara. 3) Konsumen (pedagang atau agen).
Adapun macam-macam saluran distribusi barang konsumen :

1) Produsen-Konsumen.

2) Produsen-Pengecer-Konsumen.

3) Produsen-Pedagang Besar-PengecerKonsumen.

4) Produsen-Agen-Pengecer-Konsumen.

5) Produsen-Agen-Pedagang Besar-

Pengecer-Konsumen.

\section{Promosi}

Menurut Swastha dan Irawan (2008: 99), promosi adalah arus informasi atau persuasi satu arah yang dibuat untuk mengarahkan seseorang atau organisasi kepada tindakan yang menciptakan pertukaran dalam pemasaran. Di sini perusahaanlah yang harus memberitahukan dan mendorong masyarakat untuk membeli produkproduk apakah melalui media masa atau dengan cara lain.

\section{Arti, Karakteristik dan Pemasaran Produk}

Produk salah satu alat untuk memuaskan kebutuhan dan keinginan konsumen selain kebutuhan akan jasa. Kotler (2011: 190) membagi produk menjadi tiga kelompok menurut daya tahan atau kenyataanya:

\section{Barang Tahan Lama (Durable Goods}

Barang nyata yang biasanya melayani banyak kegunaan, misalnya : Perumahan, lemari es, alat-alat mesin dan pakaian.

Barang Tak Tahan Lama (Non-Durable Goods)

Barang nyata yang biasanya dikonsumsi untuk suatu atau beberapa kegunaan. Misalnya, garam, sabun, minuman.

Jasa

Kegiatan, manfaat atau kegunaan yang ditawarkan untuk dijual. Misalnya: Reparasi. 


\section{Pengambilan Keputusan Pembelian}

Dalam pengambilan keputusan merupakan suatu proses kegiatan pembelian yang tampak hanyalah satu tahap dari keseluruhan proses pembelian konsum

Basu Swasta D , T. Hani Handoko, (2012, Hal. 103 ) proses pengambilan keputusan melalui lima tahap yaitu :

\section{Menganalisis atau Pengenalan Kebutuhan dan Keinginan}

Dalam penganalisaan kebutuhan dan keinginan suatu proses ditujukan untuk mengetahui adanya kebutuhan dan keinginan yang belum terpenuhi. Jika suatu kebutuhan diketahui, maka konsumen akan memahami adanya kebutuhan yang segera dipenuhi atau masih ditunda pemenuhannya. Tahap ini adalah proses pembelian mulai dilakukan.

\section{Pencarian Informasi dan Penilaian Sumber - Sumber}

Pencarian informasi dapat bersifat aktif atau pasif, internal atau eksternal, pencarian informasi yang bersifat aktif dapat berupa kunjungan terhadap beberapa toko untuk membuat perbandingan harga dan kualitas produk, sedangkan pencarian informasi pasif hanya dengan membaca iklan di majalah atau surat kabar tanpa mempunyai tujuan khusus tentang gambaran produk yang diinginkan.

Penilaian dan seleksi terhadap alternatif pembelian

Meliputi dua tahap yaitu menetapkan tujuan pembelian dan menilai serta mengadakan seleksi terhadap alternatif pembelian berdasarkan tujuan pembelian.

Tujuan pembelian bagi masing - masing konsumen tidak selalu sama, tergantung pada jenis produk dan kebutuhannya.

Keputusan untuk membeli

Tahapan dalam proses pengambilan keputusan pembelian dimana konsumen benar - benar membeli produk.
Keputusan untuk membeli atau tidak produk yang ditawarkan. Keputusan untuk membeli yang diambil oleh pembeli sebenarnya merupakan kesimpulan dari sejumlah keputusan, misalnya : keputusan tentang jenis produk, bentuk produk, jumlah produk dan sebagainya. Apabila produk yang dihasilkan perusahaan sesuai dengan apa yang diharapkan konsumen untuk memuaskan kebutuhan dan keinginan, maka produk tersebut mampu menarik minat untuk membeli, pengambil keputusan, pembeli dan pemakai. Di sini tugas pemasar adalah mengidentifikasi peserta pembelian lain, kriteria pembelian mereka dan pengaruh mereka terhadap pembeli. Program pemasaran harus dirancang untuk menarik dan mencapai pesasrta kunci seperti halnya Pembeli ( Jurnal Sains Pemasaran Indonesia volume IX, No. 3, Desember 2010)

\section{METODE PENELITIAN Rancangan Penelitian}

Desain penelitian yang digunakan adalah penelitian kuantitatif, Adapun jenis penelitiannya adalah eksplanatory research suatu metode dalam meneliti status sekelompok manusia, suatu obyek, suatu set kondisi, suatu sistem pemikiran ataupun suatu kelas peristiwa pada masa sekarang. (Moh. Nazir, 2009:63)

\section{Data dan Sumber Data}

Dilihat dari sumber perolehan data, atau dari mana data tersebut berasal secara umum dalam penelitian dikenal dengan data primer dan data skunder. Data yang diperlukan dalam penelitian ini adalah data primer. Data primer merupakan sumber data penelitian yang diperoleh secara langsung dari sumber aslinya (tidak melalui perantara). Data primer dapat berupa opini subyek (orang) secara individual atau kelompok, hasil observasi terhadap suatu benda (fisik), 
kejadian atau kegiatan dan hasil - hasil kuesioner.

\section{Populasi dan Sampel}

Arikunto (2010: 173) berpendapat bahwa populasi adalah keseluruhan subyek penelitian. Sedangkan menurut Sugiyono (2012: 119), populasi dapat didefinisikan sebagai wilayah generalisasi yang terdiri dari obyek atau subyek yang mempunyai kuantitas dan karakteristik tertentu yang ditetapkan oleh peneliti. Populasi pada penalitian ini adalah Konsumen di CV.Paradila sebanyak 1650 Konsumen dan CV.Bintang Mas sebanyak 1350 sehingga total populasi 3000 konsumen.

Sampel ialah bagian dari jumlah dan karakteristik yang dimiliki oleh populasi tersebut,untuk menentukan jumlah sampel penelitian tersebut dapat digunakan rumus Slovin, yaitu:

$\mathrm{n}=\frac{N}{\mathrm{I}+N \underline{E}^{2}}$

keterangan:

$\mathrm{n}=$ Sampel, $\mathrm{N}=$ Populasi dan $\mathrm{E}=$ Perkiraan tingkat kesalahan

Berdasarkan data diperoleh jumlah konsumen yang telah diketahui dapat ditentukan jumlah sampel untuk penelitian ini adalah:

$n=\frac{3}{1+3 \quad(U, \mathbb{1})^{2}}$

$n=\frac{3}{1+3 \quad(\mathrm{u}, 0)}$

= 96,77 (dibulatkan 97)

jumlah sampel dalam penelitian ini adalah sebanyak 97 orang.

\section{Teknik Sampling}

Dalam penelitian ini digunakan metode purposive sampling. Purposive sampling adalah teknik pengambilan sampel dengan pertimbangan tertentu (Sugiyono, 2012:216). Dengan menggunakan purposive sampling, diharapkan kriteria sampel yang diperoleh benar-benar sesuai dengan penelitian yang dilakukan dan mampu menjelaskan keadaan sebenarnya tentang obyek yang diteliti.

\section{Teknik Pengumpulan Data}

Teknik pengumpulan data yang digunakan adalah sebagai berikut:

\section{Angket (Quesioner)}

Adalah teknik pengumpulan data dengan cara mengajukan lembaran angket kepada responden yang berisikan daftar pertanyaan. Metode ini digunakan untuk mendapatkan data angket dari responden yang ada.

\section{Skala Pengukuran}

Sugiyono

mengemukakan bahwa "skala likert digunakan untuk mengukur sikap, pendapat dan persepsi seseorang atau sekelompok orang tentang fenomena sosial". Adapun Jawaban kuesioner diberi skor sebagai berikut :

a. Sangat Tidak Setuju (STS)= skor 1

b. Tidak Setuju $(\mathrm{TS})=$ diberi skor 2

c. Biasa Saja $(\mathrm{BS})=$ diberi skor 3

d. Setuju $(S)=$ diberi skor 4

e. Sangat Setuju $(\mathrm{SS})=$ diberi skor 5

\section{Definisi Operasional Variabel}

Variabel dependen/bebas(X)

adalah variabel yang menjadi pusat

perhatian peneliti.

\section{Model (X1)}

Model adalah suatu ciri yang tercemin dalam mode atau metode yang berbeda dari pengungkapan, penyajian dan menyatakannya atau konsepsi. Tjiptono,Fandy (2008: 25).Adapun indikatornya meliputi:

1. Corak warna produk .

2. Model yang sedang trend

3. Model berganti-ganti

Mutu (X2)

Mutu merupakan kualitas suatu barang akan dinilai oleh konsumen dengan melihat kemampuannya menjalankan fungsinya, Basu Swastha, 
T.Hani (2012: 147). Adapun indikator meliputi :

1. Mutu Sudah setara dengan produk lain

2. Ketahanan produk lebih baik dari produk lain

3. Mutu produk terjamin

Harga (X3)

Harga adalah jaminan uang

(ditambah beberapa produk kalau mungkin) yang dibutuhkan untuk mendapatkan sejumlah kombinasi dari produk dan pelayanannya. Adapun indikator menurut Kotler dan Amstrong (2012 : 314) meliputi:

1. Keterjangkauan harga

2. Harga sesuai kemampuan atau daya saing harga

3. Kesesuaian harga dengan kualitas produk.

4. Kesesuaian harga dengan manfaat produk

Variabel independen /Terikat, Keputusan pembelian (Y)

Keputusan pembelia merupakan hal yang sangat penting untuk mencapai keberhasilan dari suatu badan usaha seperti yang dikemukakan oleh Dutka (2011: 211) Adapun indikator dari keputusan konsumen dalam melakukan pembelian menurut Akbar dan Nizar (2011), antara lain: (1) keyakinan dalam membeli; (2) mencari informasi, (3) merencanakan pembelian, dan (4) sesuai keinginan.

\section{Analisa data}

Untuk perhitungan penelitian ini menggunakan komputer melalui program SPSS 22.0 for windows. Adapun pengujian penelitian ini digunakan uji:

\section{Uji Validitas}

Menurut Arikunto (2010:144) Uji Validitas adalah suatu ukuran yang menunjukkan tingkat-tingkat kevalidan dan kesahihan instrumen.Uji validitas digunakan untuk mengukur sah atau valid tidaknya suatu kuesioner.
Uji signifikansi dilakukan dengan membandingkan nilai $\mathrm{r}$ hitung dengan nilai $r$ tabel. Jika $r$ lebih besar dari $r$ tabel (dilihat dari $\mathrm{r}$ product moment) dan nilai $\mathrm{r}$ positif. Maka butir atau pertanyaan tersebut dikatakan valid.

\section{Uji Reabilitas}

Ghozali (2011:47) mengatakan reliabilitas adalah suatu angkayang menunjukkan konsistensi suatu alat ukur didalam mengukur objek yang sama. Pengujian reliabilitas dapat menggunakan metode Alfa cronbach, dengan cerita Alfa cronbach dari masing-masing variabel lebih dari 0.70 maka alat ukur dalam penelitian ini dapat dikatakan reliabel.

\section{Asumsi Klasik}

Uji asumsi klasik adalah dimana pengujian ini digunakan untuk memperoleh hasil/nilai yang tidak bias atau estimator linear tidak bias yang terbaik (Best Linear Unbiased Estimator/BLUE). Asumsi klasik tersebut yaitu :

\section{Multikolinearitas}

Uji multikolinearitas dalam penelitian ini adalah dengan melihat nilai Inflation Factor (VIF) pada model regresi. Menurut Santoso dalam Priyatno (2010:81) "pada umumnya jika VIF lebih besar dari 5, maka variabel tersebut mempunyai persoalan multikolinearitas dengan variabel bebas lainnya".

\section{Heteroskedastisitas}

Priyatno (2010:83) mengemukakan bahwa : Heteroskedastisitas adalah keadaan dimana terjadi ketidaksamaan varian dari residual untuk semua pengamatan pada model regresi. Uji heteroskedastisitas digunakan untuk mengetahui ada atau tidaknya ketidaksamaan varian dari residual pada model regresi. Prasyarat yang harus dipenuhi dalam model regresi adalah tidak adanya gejala heteroskedastisitas. Dasar pengambilan keputusan : 
1. Jika ada pola tertentu, seperti titiktitik (poin-poin) yang ada membentuk suatu pola tertentu yang teratur (bergelombang, melebar kemudian menyempit), maka telah terjadi heteroskedastisitas.

2. Jika tidak ada pola yang jelas, serta titik-titik menyebar di atas dan di bawah angka 0 pada sumbu $\mathrm{Y}$, maka tidak terjadi heteroskedastisitas.

\section{Uji Autokorelasi}

Salah satu syarat yang harus dipenuhi oleh model regresi adalah tidak ada autokorelasi. Menurut Widayat dan Amirullah (2012:108) Untuk mendeteksi adanya autokorelasi adalah dari besaran Durbin Watson. Secara umum nilai Durbin Watson yang bisa diambil patokan menurut Priyatno (2010:219) adalah:

a. Angka D-W di bawah -2 berarti ada autokorelasi positif.

b. Angka D-W diantara -2 sampai +2 berarti tidak ada autokorelasi.

c. Angka D-W di atas +2 berarti autokorelasi negatif.

\section{Uji Normalitas}

Menurut Ghozali (2011) Distribusi normal akan membentuk satu garis diagonal jika distribusi normal data adalah normal maka garis menggambarkan data. Sesungguhnya akan mengikuti garis diagonalnya atau dengan kata lain media grafik histogram dan grafik Normal plot.

1. Jika data menyebar garis diagonal dan mengikuti arah garis diagonal atau grafik histogram menunjukkan pola distribusi normal maka model regresi memenuhi asumsi normalitas.

2. Jika data menyebar garis diagonal dan mengikuti arah garis diagonal atau grafik histogram tidak menunjukkan pola distribusi normal maka model regresi tidak memenuhi asumsi normalitas.

\section{Regresi linier berganda}

Yaitu untuk menguji atau melakukan estimasi dari suatu permasalahan yang terdiri lebih dari satu variabel bebas. Secara umum persamaan regresi linier berganda dapat dituliskan sebagai berikut:

$Y=\beta_{0}+\beta_{1} X_{1}+\beta_{2} X_{2}+\beta_{2} X_{2}+e$

Keterangan:

$\mathrm{Y}=$ Keputusan Pembelian, $\mathrm{X}_{1}=$ Model, $\mathrm{X}_{2}=$ Mutu, $\mathrm{X}_{3}=$ Harga dan $\mathrm{E}=$ Kesalahanpenggangu (error disturbance)(Sugiyono, 2010:221)

Uji F

Uji ini digunakan untuk mengetahui pengaruh bersama-sama variabel bebas terhadap varibel terikat. Dimana $F_{\text {hitung }}>$ $\mathrm{F}_{\text {tabel, }}$ maka $\mathrm{H} 1$ diterima atau secara bersama-sama variabel bebas dapat menerangkan variabel terikatnya secara serentak. Sebaliknya apabila $\mathrm{F}_{\text {hitung }}<$

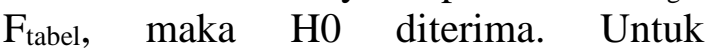
mengetahuinya digunakan probability sebesar 5\% $(\alpha=0,05)$.

- Jika sig > $\dot{\alpha}(0,05)$, maka H0 diterima H1 ditolak.

- Jika sig < $\dot{\alpha}(0,05)$, maka H0 ditolak H1 diterima.

Uji t

Uji ini digunakan untuk mengetahui signifikansi dari pengaruh variabel independen terhadap variabel dependen secara individual. Uji $\mathrm{T}$ bisa dilihat pada tingkat signifikansinya:

- Jika tingkat signifikansi $<0,05$, maka $\mathrm{H}_{0}$ ditolak dan $\mathrm{H}_{1}$ diterima

- Jika tingkat signifikansi > 0,05, maka $\mathrm{H}_{0}$ diterima dan $\mathrm{H}_{1}$ ditolak

\section{Analisis Koefisien Determinasi}

Berganda $\left(\mathrm{R}^{2}\right)$

Dalam beberapa model biasanya perhitungan $\left(\mathrm{R}^{2}\right)$ adalah kurang dari 1 
tetapi yang sering terjadi adalah $\left(\mathrm{R}^{2}\right)$ berada antara 0,2 sampai 0,8 , Nilai $\mathrm{R}^{2}$ ( koefisien determinasi ) terletak antara 0 dan 1 . Jika nilai $\mathrm{R}^{2}=1$ berarti 100 persen total variasi variabel dependen diterangkan oleh variabel independen. Jika $\mathrm{R}^{2}=0$ berarti tidak ada variasi $\mathrm{y}$ yang di terangkan oleh X1 maupun X2.

\section{HASIL DAN PEMBAHASAN Distribusi Frekuensi Variabel Penelitian Variabel Model (X1)}

Berdasarkan hasil penelitian yang telah dilakukan terhadap 97 responden maka diperoleh data.Data variabel sebagai berikut:

Tabel 5.6 Rekapitulasi jawaban model produk

\begin{tabular}{|l|l|c|c|c|c|c|c|}
\hline No & Daftar pertanyaan & STS & TS & BS & S & SS & Total \\
\hline 1 & X1.1 & 1 & 0 & 7 & 76 & 13 & 97 \\
\hline 2 & X1.2 & 0 & 0 & 0 & 42 & 55 & 97 \\
\hline 3 & X1.3 & 0 & 0 & 16 & 69 & 12 & 97 \\
\hline \multicolumn{2}{|l|}{ Jumlah } & 1 & 0 & 23 & 187 & 80 & 291 \\
\hline \multicolumn{2}{|l|}{ Rata-rata } & 0,5 & 0 & 11,5 & 93,5 & 40 & 145,5 \\
\hline
\end{tabular}

Sumber : Data Primer diolah (2018)

Berdasarkan tabel diatas jawaban responden menunjukan bahwa sebagai besar responden memberikan tanggapan setuju dan sangat setuju

\section{Mutu}

Distribusi frekuensi dari item-item pernyataan mutu Produk tersebut seperti pada tabel dibawah ini.

Tabel 5.7 Rekapitulasi jawaban Mutu produk

\begin{tabular}{|l|l|l|l|l|l|l|l|}
\hline No & Daftar pertanyaan & STS & TS & BS & S & SS & Total \\
\hline 1 & X2.1 & 2 & 2 & 3 & 51 & 39 & 97 \\
\hline 2 & X2.2 & 0 & 6 & 18 & 42 & 31 & 97 \\
\hline 3 & X2.3 & 0 & 0 & 13 & 59 & 25 & 97 \\
\hline Jumlah & 2 & 8 & 34 & 152 & 95 & 291 \\
\hline \multicolumn{2}{|l|}{ Rata-rata } & 1 & 4 & 17 & 76 & 47,5 & 145,5 \\
\hline
\end{tabular}

Berdasarkan tabel diatas jawaban responden menunjukan bahwa sebagai besar responden memberikan tanggapan setuju dan sangat setuju tehadap variabel mutu

\section{Harga (X3)}

Distribusi frekuensi dari item-item pernyataan Harga seperti dibawah ini.

Tabel 5.8 Rekapitulasi jawaban Harga

\begin{tabular}{|l|l|l|l|l|l|l|l|}
\hline No & Daftar pertanyaan & STS & TS & BS & S & SS & Total \\
\hline 1 & X3.1 & 1 & 1 & 10 & 79 & 6 & 97 \\
\hline 2 & X3.2 & 0 & 3 & 8 & 75 & 11 & 97 \\
\hline 3 & X3.3. & 0 & 0 & 16 & 70 & 11 & 97 \\
\hline 4 & X3.4 & 0 & 0 & 8 & 76 & 13 & 97 \\
\hline \multicolumn{2}{|l|}{ Jumlah } & 1 & 4 & 42 & 300 & 41 & 388 \\
\hline
\end{tabular}


Berdasarkan tabel diatas jawaban responden menunjukan bahwa sebagai besar responden memberikan tanggapan setuju dan sangat setuju .

\section{Keputusan Pembelian (Y)}

Distribusi Keputusan Pembelian tersebut seperti pada tabel dibawah ini.

Tabel 5.9 Rekapitulasi jawaban Keputusan Pembelian

\begin{tabular}{|l|l|l|l|l|l|l|l|}
\hline No & Daftar pertanyaan & STS & TS & BS & S & SS & Total \\
\hline 1 & Y1 & 1 & 3 & 3 & 53 & 37 & 97 \\
\hline 2 & Y2 & 1 & 1 & 0 & 40 & 55 & 97 \\
\hline 3 & Y3 & 0 & 0 & 16 & 69 & 12 & 97 \\
\hline 4 & Y4 & 0 & 0 & 8 & 76 & 13 & 97 \\
\hline \multicolumn{2}{|l|}{ Jumlah } & 2 & 4 & 27 & 238 & 117 & 388 \\
\hline \multicolumn{2}{|l|}{ Rata-rata } & 0,8 & 1,6 & 10,8 & 95,2 & 46,8 & 155,2 \\
\hline
\end{tabular}

Sumber : Data primer diolah (2018)

Berdasarkan tabel diatas jawaban responden menunjukan bahwa sebagai besar responden memberikan tanggapan setuju dan sangat setuju tehadap variabel keputusan pembelian.

\section{Uji Validitas}

Hasil Uji Validitas perhitungan terlihat pada tabel dibawah ini:

Tabel 5.10 Uji Validitas

\begin{tabular}{|c|c|c|c|c|}
\hline Variabel & Item & rhitung & & rtabel \\
\hline \multirow[t]{3}{*}{ Model (X1) } & $\mathrm{X} 1.1$ & 0,834 & $>$ & 0,198 \\
\hline & $\mathrm{X} 1.2$ & 0,724 & $>$ & 0,198 \\
\hline & $\mathrm{X} 1.3$ & 0,863 & $>$ & 0,198 \\
\hline \multirow[t]{3}{*}{ Mutu (X1) } & $\mathrm{X} 2.1$ & 0,714 & $>$ & 0,198 \\
\hline & $\mathrm{X} 2.2$ & 0,872 & $>$ & 0,198 \\
\hline & $\mathrm{X} 2.3$ & 0,856 & $>$ & 0,198 \\
\hline \multirow[t]{4}{*}{ Harga (X1) } & $\mathrm{X} 3.1$ & 0,746 & $>$ & 0,198 \\
\hline & $\mathrm{X} 3.2$ & 0,755 & $>$ & 0,198 \\
\hline & X3.3 & 0,809 & $>$ & 0,198 \\
\hline & X3.4 & 0,725 & $>$ & 0,198 \\
\hline \multirow{4}{*}{$\begin{array}{c}\text { Keputusan } \\
\text { Pembelian (Y) }\end{array}$} & Y.1 & 0,817 & $>$ & 0,198 \\
\hline & Y.2 & 0,824 & $>$ & 0,198 \\
\hline & Y.3 & 0,731 & $>$ & 0,198 \\
\hline & Y.4 & 0,703 & $>$ & 0,198 \\
\hline
\end{tabular}

Sumber: Data primer, 2018 diolah

Dari tabel diatas dikarenakan nilai korelasi masing-masing item menunjukkan angka yang lebih besar dari pada rtabel pada signifikansi pertanyaan memiliki rhitung $>\operatorname{rtabel}(0,198)$. 


\section{Uji Reliabilitas}

Hasil Uji reabilitas terlihat pada tabel berikut:

Tabel 5.11 Uji Reliabilitas X1

\begin{tabular}{|r|r|}
\hline Cronbach's Alpha & N of Items \\
\hline, 732 & 3 \\
\hline
\end{tabular}

Sumber : Data diolah SPSS 22, 2018

Tabel 5.12 Uji Reliabilitas X2

\begin{tabular}{l|l} 
Cronbach's Alpha & $\mathrm{N}$ of Items \\
\hline
\end{tabular}

, 728

Sumber : Data diolah SPSS 22, 2018

Tabel 5.13 Uji Reliabilitas X3

\begin{tabular}{|r|c|}
\hline Cronbach's Alpha & N of Items \\
\hline, 752 & 4 \\
\hline
\end{tabular}

Sumber : Data diolah SPSS 22, 2018

Tabel 5.14 Uji Reliabilitas Y

\begin{tabular}{|l|l} 
Cronbach's Alpha & N of Items \\
\hline
\end{tabular}

, 805

Sumber : Data diolah SPSS 22, 2018

Dari hasil yang didapat pada tabel diatas di atas maka Variabel X1,X2,X3 dan Y reliabel karena nilai Cronbach's Alpha $>0.70$.

\section{Uji Asumsi Klasik}

\section{Uji Multikolinieritas}

Hasil Uji Multikolinieritas seperti tabel dibawah ini:

Tabel 5.15 Uji Multikolinieritas

\begin{tabular}{|c|c|c|c|}
\hline \multirow[b]{2}{*}{ Model } & & \multicolumn{2}{|c|}{ Collinearity Statistics } \\
\hline & & Tolerance & VIF \\
\hline 1 & (Constant) & & \\
\hline & Model &, 266 & 3,766 \\
\hline & Mutu & ,447 & 2,239 \\
\hline & Harga & ,246 & 4,062 \\
\hline
\end{tabular}

Sumber : Data primer diolah (2018)

Dari tabel diatas menunjukkan bahwa nilai Variance Inflation Factor $(\mathrm{VIF})>0,1$ dari masing-masing variabel independen tidak dan nilai VIF $<10$. tidak mendukung multikolonieritas

\section{Uji Heteroskedastisitas}

Hasil Uji Heteroskedastisitas berikut ini:

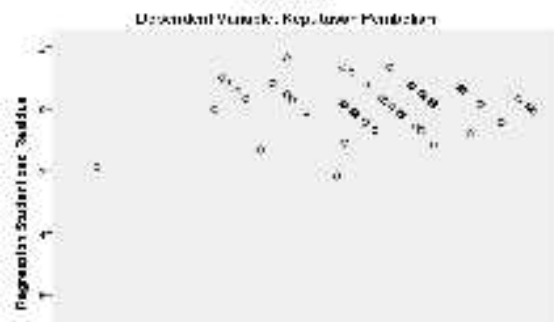

Gambar 5.2 Hasil scatterplot Uji

Heteroskedastisitas

Sumber : Lampiran 6 SPSS 22 (2018)

Dari gambar 5.2 menunjukkan bahwa penyebaran data menyeluruh pada sampel dan menyebar diatas dan dibawah angka nol pada sumbu Y maka dapat disimpulkan bahwa dalam penelitian ini tidak terdapat heterokedastisitas

\section{Uji Normalitas}

Hasil uji normalitas dapat dilihat dalam gambar berikut:

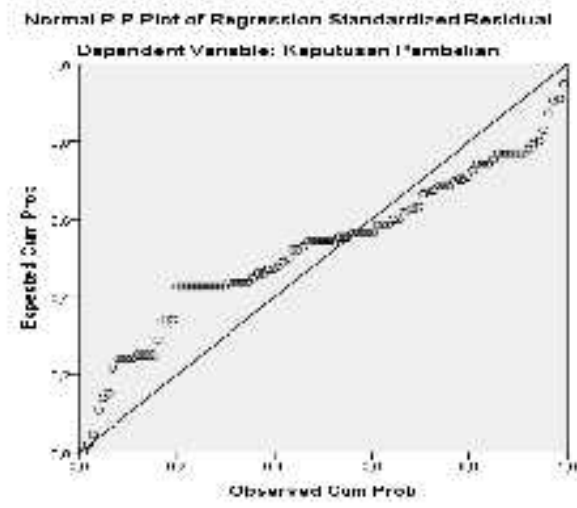

Gambar 5.3 Uji Normalitas Sumber : Data primer ,diolah (2018)

Dari gambar 5.3 menunjukkan bahwa gambar mengikuti garis melintang sehingga dapat dikatakan data berdistribusi normal

\section{Autokorelasi}

Berikut ini adalah hasil pengujian autokrelasi:

\section{Tabel 5.16 autokrelasi}

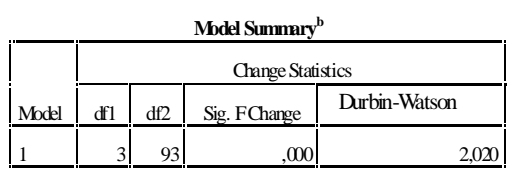

a. Predictors: (Constant), Harga, Mutu, Model b. Dependent Variable: Keputusan Pembelian Sumber : Data primer, diolah (2018) (2018)

Dari tabel 5.16 menunjukkan bahwa Durbin-Watson 2,020 dan 
termasuk dalam kategri $1,65<\mathrm{DW}<2,35$ atau $1,65<2,020<2,35$. Sehingga dapat disimpulkan tidak terdapat autokrelasi dalam penelitian ini.

\section{Regresi Linier Berganda}

Hasil regresi seperti dalam tabel di bawah ini :

\section{Tabel 5.17 Koefisien Regresi Linier Berganda}

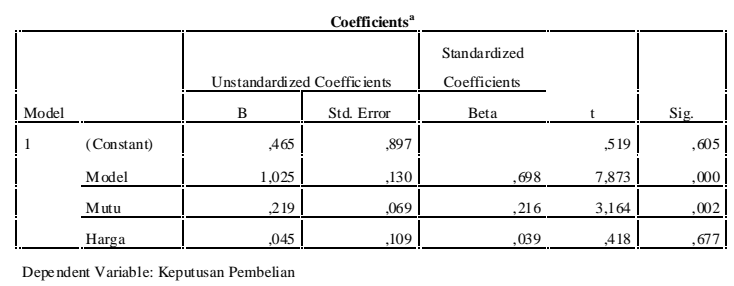

Dari table di atas, maka persamaan regresi linier berganda yang terbentuk adalah sebagai berikut

$\mathrm{Y}=0,465+1,025 \mathrm{X} 1+0,219 \mathrm{X} 2+0,045$ $\mathrm{X} 3+\mathrm{e}$

Keterangan :

1. Nilai a (konstanta) sebesar 0,465 artinya jika X1, X2 dan X3 konstan maka Keputusan Pembelian adalah sebesar 0,465 satuan.

2. Koefisien regresi X1 model sebesar 1,025 menunjukan bahwa model mempunyai pengaruh sebesar 1,025 terhadap Keputusan Pembelian Hal ini berarti peningkatan pengaruh model sebesar 1 satuan akan mengakibatkan kenaikan Keputusan Pembelian sebesar 102,5 dengan asumsi X1 konstan dan sebaliknya

3. Koefisien regresi X2 mutu sebesar 0,219 menunjukan bahwa mutu mempunyai pengaruh sebesar 0,219 terhadap Keputusan Pembelian Hal ini berarti peningkatan pengaruh mutu sebesar 1 satuan akan mengakibatkan kenaikan Keputusan Pembelian sebesar 0,219 dengan asumsi X2 konstan dan sebaliknya

4. Koefisien regresi X3 Harga sebesar 0,045 menunjukan bahwa harga mempunyai pengaruh sebesar 0,045 terhadap Keputusan Pembelian Hal ini berarti peningkatan pengaruh harga sebesar 1 satuan akan mengakibatkan kenaikan Keputusan Pembelian sebesar 0,045 dengan asumsi X3 konstan dan sebaliknya

\section{Uji F}

Hasil uji F dalam tabel di bawah ini :

Tabel 5.16 Hasil Uji F (Test)

\begin{tabular}{|c|c|c|c|c|c|}
\hline \multicolumn{2}{|c|}{ Modd } & df & MeanSquare & $\mathrm{F}$ & $\mathrm{Sg}$ \\
\hline 1 & Pegression & 3 & 91,430 & 128,517 &,$\infty 0^{b}$ \\
\hline & Pesidal & 93 & ,711 & & \\
\hline & Todal & 96 & & & \\
\hline
\end{tabular}

a Dependert Varidble: Keputusan Penbelian

Sumber : Data Primer diolah 2018

Dari hasil uji ANOVA $^{\mathbf{b}}$ atau $F$ test didapat $\mathrm{F}$ hitung yaitu 128,517dengan tingkat signifikan ,000 karena probabilitas $(, 000)$ jauh lebih kecil dari 0,05, Sedangkan $\mathrm{F}$ tabel dengan df $2=97$ (n-k-1) sebesar 2,70. Hal ini berarti $F_{\text {hitung }}$ $>\mathrm{F}$ tabel $(128,517>2,70)$. Hal ini membuktikan bahwa variabel faktor model,mutu dan harga secara simultan berpengaruh terhadap Keputusan Pembelian Produk sarung tenun

Uji t

Hasil Uji t penelitian ini sebagai berikut :

\section{Tabel 5.17 Uji T}

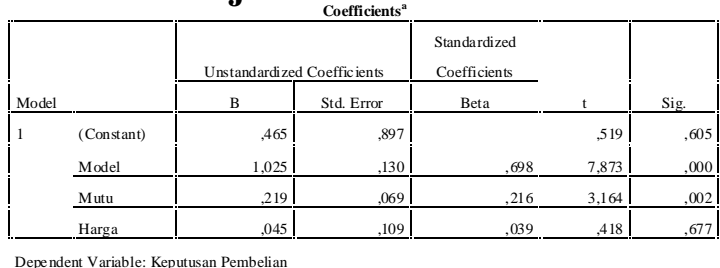


Sumber : Data Primer diolah 2018

Dari hasil hasil analisa diatas dapat

dijelaskan sebagai berikut:

1. Nilai t hitung untuk X1 ( Faktor Model) adalah 7,873 sedangkan nilai $\mathrm{t}$ tabel dan derajat kebebasan $\mathrm{df}=(\mathrm{n}$ $\mathrm{k}-1)$ adalah 1,661 dengan tingkat signifikan 0,000 . Sehinga $t_{\text {hitung }}>$ $t_{\text {tabel }}(7,873>1.661)$. Jadi dari analisa diatas dapat dijelaskan bahwa $\mathrm{H}_{0}$ ditolak dan $\mathrm{H}_{1}$ diterima, artinya secara parsial faktor model memiliki pengaruh yang signifikan terhadap Keputusan Pembelian Produk sarung tenun pada usaha kecil, dan menengah (UKM) Parengan Maduran lamongan.

2. Nilai $\mathrm{t}$ hitung untuk $\mathrm{X} 2$ (Mutu) adalah 3,164 sedangkan nilai t tabel dengan tingkat signifikan 0,002 dan derajat kebebasan $\mathrm{df}=(\mathrm{n}-\mathrm{k}-1)$ adalah 1.661. Sehinga $t_{\text {hitung }}>t_{\text {tabel }}(3,164>$ 1.661). Jadi dari analisa diatas dapat dijelaskan bahwa $\mathrm{H}_{0}$ diterima dan $\mathrm{H}_{1}$ ditolak, artinya secara parsial mutu memiliki memiliki pengaruh yang signifikan terhadap Keputusan Pembelian Produk sarung tenun pada usaha kecil, dan menengah (UKM) Parengan Maduran lamongan

3. Nilai $\mathrm{t}$ hitung untuk X3 (Harga) adalah 0,418 sedangkan nilai $\mathrm{t}$ tabel dengan tingkat signifikan 0,667 dan derajat kebebasan $\mathrm{df}=(\mathrm{n}-\mathrm{k}-1)$ adalah 1.661. Sehinga thitung $>$ ttabel $(0,418$ $<$ 1.661). Jadi dari analisa diatas dapat dijelaskan bahwa $\mathrm{HO}$ ditolak dan H1 diterima, artinya secara parsial harga tidak memiliki memiliki pengaruh yang signifikan terhadap Keputusan Pembelian Produk sarung tenun pada usaha kecil, dan menengah (UKM) Parengan Maduran lamongan

\section{Uji Kofisien Determinasi}

Hasil uji koefisien determinasi seperti tabel dibawah ini :

Tabel. 5.17 Uji determinasi

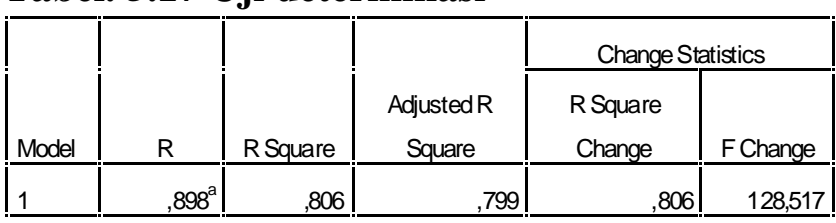

Sumber : Data primer diolah 2018

Dari data diatas dapat disimpulkan bahwa nilai Adjust $\mathrm{R}=0,799^{\mathrm{a}}$ artinya hubungan $\mathrm{x}_{1} \mathrm{x}_{2}$ dan $\mathrm{x}_{3}$ terhadap $\mathrm{y}$ sangat kuat karena mendekati nilai 1 , sedangkan nilai $\mathrm{R}^{2}$ sebesar 0,799 artinya kemampuan variabel bebas dalam menjelaskan keragaman variabel terikatnya adalah sebesar $79,9 \%$ dan terdapat $20,1 \%$ keragaman variabel terikat yang dijelaskan oleh faktor lain.

\section{SIMPULAN DAN SARAN}

\section{Simpulan}

a. Adanya pengaruh secara parsial faktor model dan mutu terhadap keputusan pembelian produk sarung tenun pada UKM CV.Paradila dan CV. Bintang Mas Lamongan ,kecuali Harga Kurang signifikan

b. Adanya pengaruh secara simultan faktor model,mutu Model,Mutu dan harga terhadap keputusan pembelian produk sarung tenun pada UKM CV.Paradila dan CV. Bintang Mas Lamongan

c. Hasil uji $\mathrm{T}$ diketahui bahwa model yang paling berpengaruh terhadap keputusan keputusan pembelian produk sarung tenun pada UKM CV.Paradila dan CV. Bintang Mas Lamongan

\section{Saran}

1. Ada pengaruh pengaruh variabelvariabel Model, mutu terhadap 
keputusan pembelian kecuali harga kurang signifikan,, maka sebaiknya manajemen UKM CV. Bintang Mas dan UKM CV. Paradila lebih memperhatikan hal tersebut terutama model harus inovasi dan diciptakan model trend terkini sehingga menghasilkan produk yang bermutu bisa bersaing di era global ini. Pengembangan berikutnya kearah pengabdian masyarakat dengan bantuan ristekdikti untuk usaha pengembangan model

2. Ucapan terima kasih kami tujukan kepada Direktorat jendral Penelitian dan Pengabdian Masyarakat Dirjen Dikti yang mendanai Penelitian ini Melalui Penelitian Dosen Pemula (PDP 2018).

\section{DAFTAR PUSTAKA}

Akbar. 2011 Peran Harga Sebagai Indikator Kualitas Jasa Persepsi dan Pengaruh Terhadap Kemungkinan Membeli Konsumen. Fokus Manajerial, Vol. 2, No. 2, 101-120

Arikunto, Suharsimi, 2010. Prosedur Penelitian Suatu Pendekatan Praktek, Jakarta: Penerbit Rineka

Ghozali,Imam. (2011). Aplikasi Analisis Multivariate dengan Program SPSS. Semarang : Badan penerbitUndip.

Basu Swastha D., Handoko, T. Hani. 2012. Manajemen Pemasaran. Analisis Perilaku Konsumen. Edisi Pertama. BPFE, Yogyakarta.
Basu, Swasta dan Irawan, 2008. Manajemen Pemasaran Modern. Yogyakarta: Liberty

Kotler, Philip,2011. Manajemen Pemasaran di Indonesia : Analisis, Perencanaan,. Implementasi dan Pengendalian. Jakarta : Penerbit Salemba Empa

Kotler Philip, Amstrong Gary. 2012. Prinsip-prinsip Pemasaran, Edisi ke-12. Penerbit Erlangga

Priyatno, Duwi, 2010. Paham Analisa Statistik Data dengan SPSS. Cetakan Pertama. Yogyakarta : Mediakom

Tjiptono, Fandy, 2008. Strategi Pemasaran, Edisi 3, ANDI: Yogyakarta

Winardi,2008. Promosi dan marketing mix, Mandar maju. Bandung

Sugiyono, 2010. Metode Penelitian Bisnis. Bandung: Alfabeta.

Sugiyono, 2012. Metode Penelitian Bisnis. Bandung: Alfabeta

Jurnal Sains Pemasaran Indonesia, Muhammad Rhendria Dinawan, Volume IX, No. 3, Desember 2010, http//:

www.ejournal.undip.ac.id/index.ph p/jspi/article/download/14111/1095 6. Akses tgl 16-06-2017

Jurnal Penelitian STAIN Kudus, Tina Martini. Vol. 9, No. 1, Februari 2015,http//:journal.stainkudus.ac.id /index.php/jurnalPenelitian/article/ download/854/802. Akses tgl1806-2017 